\title{
Metastatic adenocarcinoma of the colon in a 21-year-old African-American woman
}

\author{
Raya Saba, Shawn G Kwatra, Mubeenkhan Mohammedabdul, Aibek E Mirrakhimov
}

Department of Internal Medicine, Saint Joseph Hospital, Chicago, Illinois, USA

Correspondence to Dr Aibek Mirrakhimov, amirrakhimov1@gmail.com

\section{DESCRIPTION}

A 21-year-old woman was admitted to the hospital because of sudden onset of severe abdominal pain, nausea and vomiting. The patient also experienced decreased appetite and non-intentional weight loss of approximately $45.3 \mathrm{~kg}$ during the past year. Family history was positive for colon cancer in the patient's maternal grandmother (diagnosed in her 40s), and two maternal aunts diagnosed at ages 34 and 38, respectively. One of the patient's aunts tested positive for Lynch syndrome; however the patient did not undergo this testing because of personal wishes. It is important to mention that screening for Lynch syndrome is recommended at age 20 or 10 years earlier before the onset of colon cancer in a first-degree relative ${ }^{12}$

CT of the abdomen showed multiple masses in the liver, descending colon and pelvis (figure 1). An exploratory laparoscopy with biopsy was subsequently performed, and a diagnosis of stage IV adenocarcinoma of the colon with multiple metastases to the liver, abdomen and pelvis was established. The patient received her first cycle of chemotherapy before being discharged.

Ten days later the patient was re-admitted for constipation accompanied by progressively worsening abdominal pain of 3 days duration. Repeat CT at this time showed progression of the large mass with solid and cystic components noted within the mid-abdomen and pelvis.

The patient had a prolonged stay with frequent intensive care unit transfers and continued to receive chemotherapy, radiotherapy and an intensive pain control regimen. Chemotherapy and radiation therapy were eventually stopped after 1 month because of poor prognosis. Efforts were directed towards comfort care and pain control.

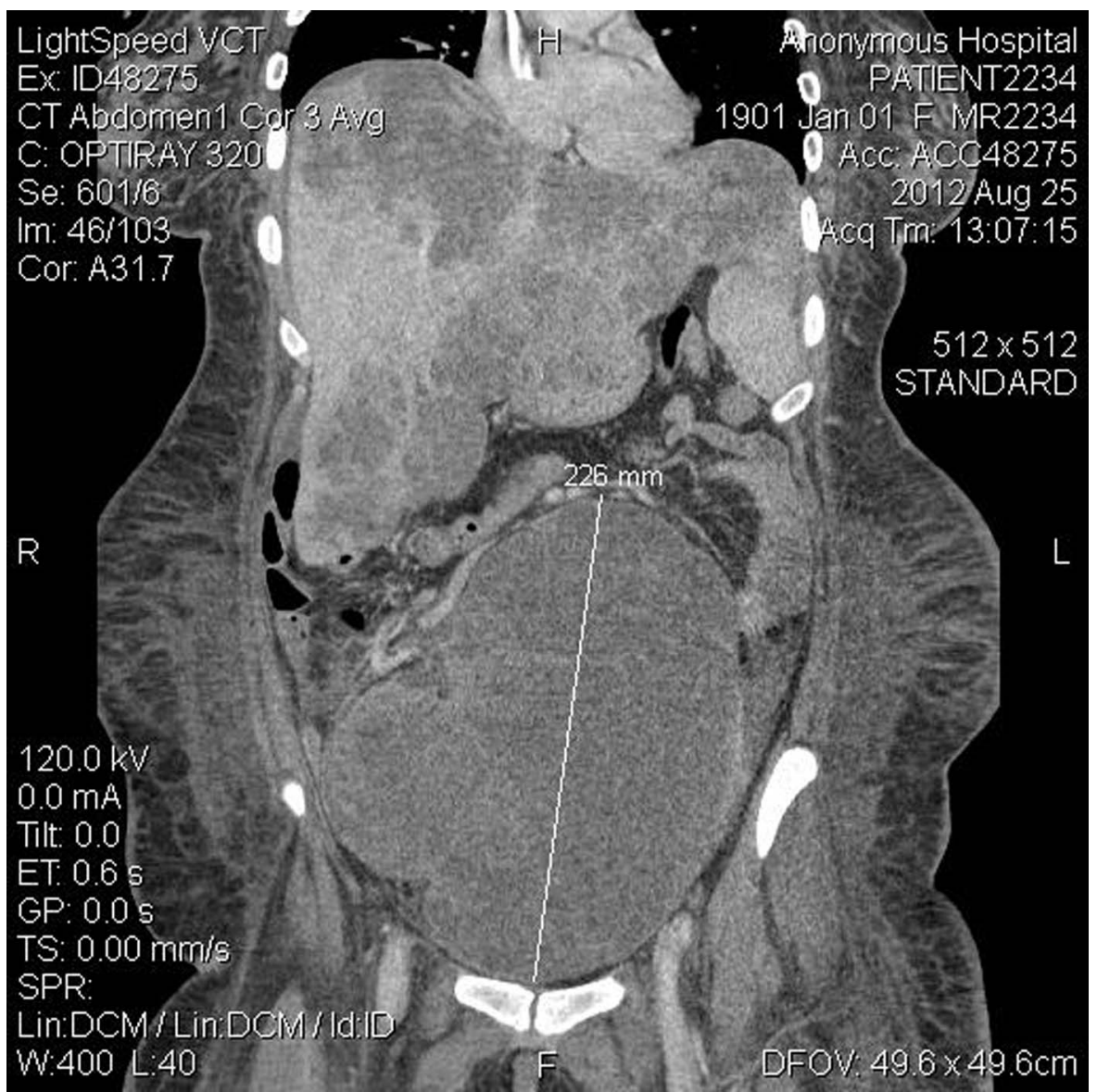

Figure 1 Abdominal and pelvic CT showing hypodense lesions in the liver and a huge pelvic mass (was found to be metastatic in nature). 


\section{Learning points}

- Familial colon cancer despite being relatively rare can be seen by every clinician at any particular period of time as early as at 10 years old.

- Abdominal and pelvic discomfort in a young patient with a family history of Lynch syndrome should raise suspicion for intra-abdominal or pelvic malignancy.
Competing interests None.

Patient consent Obtained.

Provenance and peer review Not commissioned, externally peer reviewed.

\section{REFERENCES}

1 Colas C, Coulet F, Surcek $\mathrm{M}$, et al. Lynch or not Lynch? Is that always a question? Adv Cancer Res 2012;113:121-66.

2 Jasperson KW, Tuohy TM, Neklason DW, et al. Hereditary and familial colon cancer. Gastroenterology 2010;138:2044-58.

Copyright 2013 BMJ Publishing Group. All rights reserved. For permission to reuse any of this content visit

http://group.bmj.com/group/rights-licensing/permissions.

BMJ Case Report Fellows may re-use this article for personal use and teaching without any further permission.

Become a Fellow of BMJ Case Reports today and you can:

- Submit as many cases as you like

- Enjoy fast sympathetic peer review and rapid publication of accepted articles

- Access all the published articles

- Re-use any of the published material for personal use and teaching without further permission

For information on Institutional Fellowships contact consortiasales@bmjgroup.com

Visit casereports.bmj.com for more articles like this and to become a Fellow 